\title{
CAPITALISM, CORPORATE LIBERALISM AND SOCIAL POLICY: THE ORIGINS OF THE SOCIAL SECURITY ACT OF 1935*
}

Barbara G. Brents

University of Missouri-Columbia

Mid-American Review of Sociology, 1984, Vol. IX, No. 1:23-40

This paper looks at the involvement and influence of capitalists on the Social Security Act of 1935. Instead of positing direct corporate control, the research shows how social security was formulated within a corporate liberal ideological framework which defined problems and their solutions in terms of putting the maintenance of capitalism above the needs of individual workers. This framework set the limits of the social insurance debates long before the act itself was written. The thesis is that the Social Security Act came about as a result of an interplay between the environment and an ideology advanced by corporate leaders and reform-minded academicians.

The Social Security Act of 1935 represents the first legislation in which the United States government acknowledged a duty to guarantee economic security against the hazards of old age and unemployment as a right not based on need. But there has been a great deal of criticism of welfare policies of the capitalist state for contributing more to the maintenance of the existing capitalist system and its inequalities than meeting needs of individuals (Gough, 1979; Ginsburg, 1979). With this issue in mind, this paper will look at the involvement and influence of capitalists in the formation of the Social Security Act of 1935 in order to explore the relationship between the economy and the state in framing social policy. Far from arguing an instrumentalist view (that corporate leaders directly control policy formation), this research shows how the Social Security Act came about because of the way problems were framed and solutions formulated which held the interests of capital foremost, long before the act was ever conceived.

* This work is drawn from "The Origins of the Social Security Act of 1935: Policy Formation in Capitalist Society," a master's thesis at the University of MissouriColumbia, 1983. Thanks to the thousands who helped with that project, particularly Craig Jenkins and Karen Altergott, and Al DiChiara and Teri Shumate who helped with this draft. Also, thanks to the Midwest Council for Social Research in Aging for support. 
The process of policy formation has been the subject of much attention by those interested in a theoretical understanding of the relation between the state and the economic sector in capitalist societies. Much of this research presents evidence indicating that social welfare policies are formulated by members of the corporate elite with their own interests at heart (Domhoff, 1978; Weinstein, 1968; Radosh, 1972; Kolko, 1963; O'Connor, 1973). However, the Social Security Act of 1935 has received relatively little attention in this regard. Most historical research on the formation of the Social Security Act centers on the plurality of interests involved and the compromises reached by these various interests in the final stages of the Act (Pratt, 1976; Lubove, 1968; Chambers, 1963; Sanders, 1973). On the other hand, G. William Domhoff (1970) has elaborated his instrumentalist theory by arguing that a class-conscious capitalist elite (drawn largely from big business) directly controlled the policy formation process by funding the univer sities and research organizations that did the research for the Act, and by occupying key positions in Roosevelt's executive branch of government, providing direct and conscious ruling class control over its formulation.

In contrast, Theda Skocpol (1980) argues against direct capitalist control and puts more emphasis on political and structural processes. She claims business adamantly opposed the New Deal and that the working class won these reforms because the Democratic Party, in its rise to power, needed to mobilize the support of the industrial working classes. Fred Block (1977) claims there is a division of labor between an autonomous state elite wishing to expand its own powers, and a capitalist class opposed to state expansion and normally possessing veto power by virtue of its control over the economy. During crisis periods, such as the Depression, "business confidence" is not so powerful and state managers are able to advance policies that enhance their position with the voting public. Most of these Marxist approaches seem to claim either the workings of the invisible hand of the structure of capitalism or direct capitalist control of policy formation. In addition, these accounts differ over the role of businesses in the debates, and seem to isolate the formulation of the Social Security Act from a broader social and historical context.

It is my contention that the Social Security Act was neither the product of direct corporate control, nor the invisible hand of structural processes, nor the result of compromises between various groups. This Act, which has contributed so strongly to the maintenance of the existing set of capitalist relations, was formulated with the interests of capital over the interests of workers. However, the historical framework from which social insurance arose involved both social actors linked to the corporate elite, and the political and economic structure, which they sought to influence, but which constrained them as well. The Act was the result of an interplay between a set of ideas which arose in response to an environment threatening to the position of the capitalist class, through the agency of the academicians and a range of liberal capitalists who created these ideas. To understand this, one must look at how the problems were defined and their solutions formulated, and in so doing, see how the policy options were made consistent with the maintenance of the capitalist system many years before the Act was written. Once the basic outlines were formed, no radically different social insurance proposal, either from working class movements or noncorporate liberal capitalists, could enter the policy making process.

\section{Corporate Liberalism}

Social insurance as we know it had its earliest intellectual roots in the late 19th century transformation of liberal thought from an individualist laissez faire ideology to the social responsibility, interventionist ideology of the 20th century. It was the view of this new corporate liberalism that provided justifications and methods for social insurance in America, along a course that was entirely consistent with the continuance of a capitalist system.

Twentieth century corporate liberalism, as James Weinstein (1968) defines it, involves an ideology which holds that social engineering, social efficiency and social responsibility are the means to stabilize, rationalize and expand the existing capitalist political economy, and avoid dangerous alternate forms of social organization, especially socialism. In the attempt to succeed in this endeavor, the economist arose as the technical expert who would develop government policy that would create and maintain a stable social order. As corporate liberalism developed, it succeeded in co-opting a potentially radical and often violent working class by incorporating labor representatives as junior partners in a business/government association designed to work out "rational" and "efficient" solutions to conflicts and maintain industrial peace. Terms such as efficiency and stabilization replaced justice as the main expressed goal. However, corporate liberalism, as it shall be discussed throughout this paper, cannot be viewed as a static, autonomous concept. It was a dynamic set of ideas that originated in 
the minds of humans and was both shaped by and shaped interaction in a social environment. This ideology laid the intellectual groundwork, set the ideological boundaries, and devised the methods used in the formulation of the Social Security Act as "the" solution to the problems of old age and unemployment.

Corporate liberal ideas originated in Germany in the late 1870 s and were first brought to the United States by a group of prominent American economists trained in the German Historical School of Economics centered at the University of Heidelberg. Contrary to classical economics and its abstract reasoning and individualistic emphasis on natural rights and natural law, this group believed economic phenomena could best be understood by using statistical investigations and inductive methods to shape economic institutions to meet social goals through active state intervention. The members of this school formed the Union for Social Politics (Verein für Sozialpolitik) in Germany to gather economic information to meet "the acknowledged need ... of social reform in opposition to social revolution on the one hand, and to rigid laissez faire on the other" (Dorfman, 1955:21). These attempts to "meet the challenge of socialism resulted in an advanced program of social insurance, culminating in Bismark's program of sickness, accident, invalidity and old age insurance" (Dorfman, 1955:21).

The American economists from this school returned to the United States with these ideas during the late 1880s and 90s, years fraught with long and severe depressions and widespread labor unrest. Many, including some businessmen, were losing confidence in the ability of an unregulated economy to maintain social order, and these economists did much to change the scope of American economics. The work of Richard Ely in particular helped define and institutionalize emerging corporate liberal thought and subsequent notions of social insurance.

Ely, impressed with the efficiency of the German government, believed the United States government could likewise efficiently shape economic life for the good of the public. He outlined programs of social reform that resembled those of the New Deal over 40 years laterpublic housing, public work for the unemployed, child and female labor restrictions, and government insurance for protection against death, old age, sickness and accidents (Fine, 1956; Ely, 1894). His reforms had the expressed goals of avoiding socialist violence and revolution, and maintaining the existing class structure by eliminating the waste and inefficiency of the present system (Fine, 1956; Ely, 1894). Ely published 25 books and 280 pamphlets and articles before his death in 1937. His students included a long list of New Dealers, reformists, economists, sociologists and others who became important in forming American social policy during the first half of the twentieth century.

\section{Liberal Businessmen Join with Academia}

While a large majority of individuals in policy making positions and business leaders continued to espouse a laissez faire ideology well into the 1900 s, a core of business leaders, reacting to the labor unrest and radicalism, market instability and disorganized competition of the time, were reassured by these new economic ideas that promised greater control over the economic environment. These business leaders joined with Richard Ely and other like-minded academics to form the National Civic Federation in 1901, the American Association for Labor Legislation (AALL) in 1906, the University of Wisconsin industrial research group in 1904, the Special Conference Committee (later the Business Advisory Council) in 1919, the Twentieth Century Fund, the National Bureau of Economic Research, the National Industrial Conference Board, the Brookings Institute, the Taylor Society, and Industrial Relations Counsellors. ${ }^{1}$

The work of these organizations as well as several prominent corporate liberal businessmen set the major lines of debate, the methods of research and the justifications for the Social Security Act of 1935. These organizations set the stage for government action on social insurance by: 1) encouraging and developing private welfare plans in liberal corporations which provided policy exemplars and experienced businessmen to help write the Social Security Act; 2) fostering federal interest and getting businessmen and academics involved in the problems of unemployment; and 3) creating policy and helping to pass state legislation which increased the acceptance of corporate liberal ideas as policy on social insurance.

\section{Private Welfare Plans}

The National Civic Federation (NCF) was the first of the policy consensus organizations to link corporate liberalism to businessadvocated social reforms. It was organized by Ely and certain liberal businessmen and ". . . championed protective labor legislation and the "right' kind of business regulation" (Domhoff, 1970:164). Their welfare committee along with the Special Conference Committee was 
crucial in educating other businesses about the need to enact corporate welfare programs to pacify workers, undercut unions, and make production more efficient. Some of the same business leaders involved in the NCF welfare department, such as Owen Young and Gerard Swope of General Electric, Henry Dennison of Dennison Manufacturing Company, Edward and Lincoln Filene of Filene Sons Department Stores, Morris Leeds of Leeds and Northrup, and Walter Teagle of Standard Oil of New Jersey were involved in the Special Conference Committee. They were leaders in urging managerial reforms, collective bargaining, trade associationism, various corporate welfare schemes, and at least minimal government involvement in the economy. Using the Special Conference Committee as a base, Swope and Teagle promoted the creation of company unions, employee pensions and insurance in the early 1920 s to restore stability to labor. Some of these welfare programs adopted by corporations (particularly General Electric and Eastman Kodak) provided important precedents for the Social Security Act, and these same men were active participants in its later formulation.

In fact, corporate liberal goals of stabilization and efficiency can clearly be seen in most of the corporate welfare plans instituted prior to the Depression. As early as 1909 in a speech to the National Civic Federation, George Perkins of International Harvester advocated death, sickness and disability insurance and pensions to stimulate initiative, strengthen cooperation and so increase earnings (Weinstein, 1968). By 1919, Dennison Manufacturing Company had a full range of labor bonuses including retirement, disability and worker representation, the first unemployment insurance program in the United States, and was able to decrease labor turnover by regularizing production and employment schedules. Railroads were early leaders in pension plans because of the expressed need to get slower, less careful, older workers out of this hazardous industry. However, many of the benefits of these early welfare plans were illusory because they were not backed by reserves. Since there were no employee contributions, employers had the right to cut benefits at any time (Greenough, 1976:36).

Gerard Swope of General Electric experimented the most in welfare plans. According to a study conducted at General Electric, efficiency peaked at age 32 and dropped in half by age 65 . Therefore, the savings from retiring older workers at half wages could be used to hire younger more efficient workers (Loth, 1958). As Swope's biographer conceded, the worker's welfare was not central to Swope's concern and simply "was a matter of efficiency" (Loth, 1958:158). Other progressive employers voiced similar justifications for their corporate welfare schemes. Dennison maintained into the 1920 s that organized cooperation with workers to improve employment standards was simply coldblooded science (Berkowitz and McQuaid, 1978:127). This kind of justification (echoed by the work of John R. Commons and followers in Wisconsin) was partially successful in convincing many other firms to enact plans.

Not all employers bought Swope and Teagle's radical plans. Post World War I corporate liberalism was highly successful, particularly in light of the labor unrest of the times, and many companies adopted reforms. But by the mid- to late-1920s, corporate liberalism began to lose its impetus. With rising wages, a quieter labor force and a stock market boom, most businesses were doing quite well without welfare plans. Only the large companies with 15,000 or more employees kept their programs (Greenough, 1976), and a core of corporate liberals continued to experiment, particularly Swope and Marion Folsom of Eastman Kodak. It was not until the Depression and the economic collapse of many of these plans that these same employers called for federal action.

These corporate welfare plans served as examples in framing the Social Security Act of 1935 . Their dominant theme was efficiencymaximum productivity as motivation for inducing older workers to retire with pensions, smoothing out cycles in employment for more efficient productivity-themes echoed by the academic arm of corporate liberalism (John Commons and the Wisconsin reformers, the AALL and the various research organizations). It is also important to note that these same liberal employers were also the ones most involved in the academic research and reform organizations, in the growing relationships between business and government, as well as the formulation of the Social Security Act.

\section{Legislative Precursors of the Social Security Act}

Although all of the organizations mentioned were involved in various ways, two groups were particularly active in pushing legislation that set precedents for the Social Security Act; the American Association for Labor Legislation and the University of Wisconsin. The University of Wisconsin had a close working relationship with the state and did much legislative research and drafting, helping Wisconsin become a model state for social reforms during the Progressive Era of 1904 to 1913. 
Richard Ely help found the group through ties with capitalists in the National Civic Federation and other contacts. His student, John Commons, essentially headed the group, did much of the legislative work for the State of Wisconsin and developed Ely's philosophies into workable, practical legislation. Commons influenced both the economists and the work of the University of Wisconsin, and the American Association for Labor Legislation. He developed what he called an American tradition of reform-working within the existing social order to very gradually enact reforms to preserve and extend opportunity for individual advancement, therefore proceeding safely and surely toward a stable social order. Commons "wanted to save capitalism by making it good" (Commons, 1934). He was also involved in the National Civic Federation, president of the National Consumer's League, director of the National Bureau of Economic Research, president of the American Economic Association in 1918 and president of the National Monetary Association (Harter, 1962:38).

Commons' method of successfully enacting reforms, including social insurance, was to convince individual businesses to implement changes within their firms, find out what worked best, and use these models to pass statewide legislation. According to Rimlinger (1971:67) social insurance made its most rapid gains where its profitability was demonstrated, and Commons was "a master in the appeal to employer self-interest for the sake of social causes," particularly in the field of workmen's compensation. As Commons himself said,

It was shown that by preventing accidents, nobody, not even the consumers by higher prices, would bear any burden in paying the benefits to workmen stipulated in the compensation laws. In other words, the appeal was made to a new kind of efficiency, efficiency in preventing accidents, by which costs of production could be reduced, with the result that prices need not be increased (1959:857).

Thus for Commons, the Wisconsin group of reformers and all their followers, the ideology of social insurance came to be centered around an appeal to employer self-interest (efficiency), not an appeal to paternalism or social solidarity (Rimlinger, 1971:67).

Charles McCarthy, head of the Wisconsin Legislative Reference Library, reiterated the link between this philosophy and Ely and his German training. Anyone who had been to Germany knew the state "must protect and invest in the life and happiness of the individual in order that the greatest prosperity might come from it and that security, peace and happiness are the best foundations of good government and prosperity" (McCarthy, 1912:161). Said McCarthy in testimony at the Commission on Industrial Relations in 1911:

The backbone here [of McCarthy's political thought] is that the state must invest in human beings in the same way as you invest in cattle on a farm. ... Y You have got to have better human beings.... A man will produce more, and the employer will get more for his money, and the state will get more out of the man, and my idea is that the state ought to invest in the health, strength, intelligence and ability of the people who make up the state (Weinstein, 1968:201).

The first unemployment insurance act in the country, passed in Wisconsin, later became the main prototype for the Social Security Act of 1935. Indeed, the Wisconsin economists later dominated the membership of the Committee on Economic Security. As an extension and practical application of the German School, the ideas of Commons and other Wisconsin academics helped further institutionalize the corporate liberal ideology for future social insurance debates. The "Wisconsin approach" of stressing social reforms where both labor and business could benefit narrowed the direction future social insurance legislation would take. The appeal to employer self-interest through efficiency helped gain the support of business leaders, which helped guarantee that this approach and not other more paternalistic or worker-initiated approaches would be taken in future policy formulation.

Far more important nationally, although working closely with the Wisconsin group in outlining the terms of the social insurance debates and influencing the form of the Social Security Act, was the American Association for Labor Legislation (Lubove, 1968; Eakins, 1966:59). The AALL was also founded by Richard Ely, and was financed in its early years by many of the same people who were involved in the National Civic Federation. Ely was its first president and John Commons was secretary from 1908 until Commons' student, John Andrews, took over as secretary and led the organization's efforts from 1910-1942. The membership of the AALL from 1906 until the 1930s included business leaders, labor leaders and academics and even a few socialists in its earlier days. Many positions of power, including several terms of the presidency were held by business leaders. 
The primary goal of the AALL was to bring about uniform labor legislation at the state level. The AALL ideology embodied many corporate liberal ideas discussed so far, such as using technical experts and scientific study to help the state regulate capitalism and enact social reforms as an alternative to socialism. It emphasized social justice arising from an efficient corporate society (Eakins, 1966; Skocpol, 1980). Clearly the organization was strongly influenced by the philosophies of Ely and Commons in stressing social reforms for maintenance of the existing capitalist order. And just as clearly, business could ally itself with these ideas for both its short and long term goals. According to Skocpol (1980:33) the AALL succeeded in putting its ideas into law because it responded to problems within the existing system, confronted the social changes of maturing capitalism and attained a consensus of cross class support.

The AALL was central in formulating the unemployment insurance debates. It established a Committee on Unemployment and sponsored two national conferences on unemployment during the Depression of 1914. It also published surveys of the national unemployment situation in 1914-15 and in 1920-21 (Lubove, 1968:59). Even more significantly, the AALL was central in enacting the Social Security Act (Witte, 1962). The AALL model unemployment insurance bill, called the American Plan, which was circulated in state legislatures and became Wisconsin law in 1932, focused on employer incentives to stabilize employment in their own firms by rewarding those having less unemployment with lower insurance rates. The Social Security Act was in part modeled after this bill.

Business and Government Partnership in Social Insurance Planning After a surge of interest in a government-business partnership that arose as a result of the cooperative planning efforts of World War I, business and government were cool toward direct government control in the economy. In the arena of labor reforms, voluntarism was the dominant theme up until the Depression. However, even during this period relationships between the federal government and businesses were developing which would set important precedents for the social insurance events of the New Deal.

During the post war depression in 1920-21, Secretary of Commerce Hoover and President Harding called a Presidential Conference on Unemployment. Delegates representing the American Association for Labor Legislation included many liberal business leaders who had enacted welfare plans in their own corporations, and many academics involved in other corporate liberal organizations. The subcommittee on Business Cycles and Unemployment chaired by Owen D. Young of General Electric and the National Bureau of Economic Research reported the need for remedies for cyclical fluctuations in employment and recommended more research on the issue. As a result, Hoover assigned the National Bureau of Economic Research the task and the Carnegie Corporation granted $\$ 50,000$ for the study (Eakins, 1966:160). The American Association for Labor Legislation, the Department of Agriculture, and the Federated American Engineering Society also contributed to the project.

The study done from 1921-24 was used by the Committee to come up with an essentially voluntaristic, but nonetheless corporate liberal, set of recommendations. The study endorsed the idea that economic slumps were caused by waste, extravagance and inefficiency, and industry should make use of technical economic information provided by the government to voluntarily regulate themselves to overcome seasonal fluctuations. In these ways, government, business, and labor would all work together for a more efficient economy. It was implicitly recognized that federal government spending could be manipulated to counter business cycles. And, although there was no recommendation for unemployment insurance, they believed the idea was worth considering. The influence of corporate liberal ideas, especially those of the American Association for Labor Legislation is obvious. The idea of smoothing business cycles to lower unemployment and increase efficiency became an important argument in the Social Security Act hearings.

The resurgence of the economy and several boom years took any sense of urgency out of the ideas of this committee. It was not until 1927 that another significant study was organized resurrecting the old Unemployment Conference of the 1921 Committee. This Committee on Recent Economic Changes consisted of members of the National Bureau for Economic Research (NBER) and business leaders. Ironically, the report, titled Recent Economic Changes in the United States, and its rosy portrait of the U.S. economy was not issued until 1929, two months after the market crash. Immediately the NBER did another report, Recent Social Trends in the U.S. (1933), which was mildly in favor of national planning, insurance programs, including unemployment insurance and progressive taxes. Putting more purchasing power in 
the hands of wage earners was among their recommendations, and this too became an important idea echoed in the hearings for the Social Security Act.

\section{The Depression}

The Depression was the final impetus toward national government action. As it became evident that the Depression was no normal slump in the business cycle, even more conservative business leaders looked to government for help. Labor unrest was increasing, and the masses of unemployed were becoming militant. With a growing business sentiment favoring state intervention, it was easier for corporate liberal leaders to gain popular acceptance and translate their ideas into laws on social insurance. Several intertwined factors stemming from the Depression led to the change in majority business opinion and the final corporate liberal decisions on the Social Security Act. The AALL increased its drive for unemployment insurance and precedent setting laws gained popularity at the state level. At the same time, worker unrest temporarily increased private pension action, and subsequent failure led business leaders to push for action. Finally, all of this corporate liberal policy planning was put into action with the formation of the Committee on Economic Security and the passage of the Social Security Act.

An interesting business-initiated plan was designed by Gerard Swope. His plan for economic recovery in 1931 included extensive welfare measures including unemployment compensation, pensions, life insurance, disability insurance and a federal body to oversee welfare schemes. These kinds of measures to help industry, said Swope, would "trickle down" to increase employment and income support for the masses, preserve earned benefits for workers who changed jobs and coordinate production and consumption (McQuaid, 1982:22-3). This plan was based on the premise that low consumption was a cause of the Depression (an idea that would be stated in the National Bureau of Economic Research 1933 Recent Social Trends Report), and that consumption would be higher if people felt safe about spending money. This sense of security would result from protection from the hazards of old age and unemployment (Loth, 1958). While Hoover rejected Swope's plan, then Governor Roosevelt supported it, and later included Swope in pre-Social Security planning.
Political History of Social Security

The political history of the Social Security bill demonstrates clearly the carrying out of the corporate liberal link between business, academicians and government. Swope and Young actively advised Roosevelt up until he appointed the Committee on Economic Security to research and write the bill, and the Committee was careful to carry out Roosevelt's wishes (Witte, 1962). Key positions on this committee were held by Wisconsin group people and AALL members, and a majority of the participants were connected in some way to corporate liberal organizations. The advisory council to the committee consisted of labor representatives, "public" members and business leaders. The businessmen were clearly those who were connected to corporate liberal ideas. There was much debate within this committee, and in Congress on the specific details of the bill, but overall the Social Security Act was framed in corporate liberal terms. In fact, the bill changed little once it was in Congress. Indeed, there were only two radical alternatives put before Congress at that time: the Townsend Bill (advocating $\$ 200$ per month for everyone over 60 ) and the Lundeen Bill (advocating benefits equal to average local wages to all workers and farmers over 18 who were unemployed through no fault of their own). But neither of these bills, nor working class movements, nor general non-corporate liberal business opposition could legitimately enter the policy making process once the basic outlines were formulated.

The corporate liberal ideology had clear hegemony and dominated Congressional debates. A survey of Congressional hearings shows that stabilization of industry was the dominant theme and debates among those involved in government, the Committee on Economic Security, and liberal industry centered around the best method of stabilization. In justifying the act to Congress, administration spokespersons, including advisory council member Marion Folsom of Kodak and other businessmen supporting the act, emphasized that unemployment insurance would stabilize the labor force as well as purchasing power, hence giving employers more predictable markets.

Even old age insurance was viewed in terms of stabilization and efficiency. According to a report published by the Social Security Board (1937:199), old age insurance was created to enhance the elderly's sense of security and confidence, get old people out of the labor market and stabilize their consumption expenditures. Hence, old age insurance was viewed as helping to solve part of the unemployment 


\section{Mid-American Review of Sociology}

problem, a problem viewed more in terms of the inefficiency of industry rather than the effects on the worker. According to Murray Latimer, who helped write the old age provisions of the Act:

There are a number of industrial companies who's level of productive efficiency has been and is being reduced by the fact that they have a number of old men whom they would like to retire but cannot on account of public pressure, and at the same time they have not sufficient funds available to start a pension system (Latimer, Senate Finance Committee Hearings, 1935:749).

After explaining how benefits would induce elders to leave the labor force, increase wages, absorb the young employed and also take the burden of support off their children, Latimer added, "nor should the advantages of the maintenance of a large and continuing stream of purchasing power directed almost entirely to consumer goods be overlooked" (Ways and Means Committee Hearings, 1935:223-4). The advantages for the stabilization of industry via production and consumption was the central theme of the debates on old age insurance.

\section{Conclusions}

The development of corporate liberalism from the German Historical School through the research and policy planning organizations composed of capitalists and academics gradually altered views toward social insurance by encouraging businesses to believe it could help expand their industries as well as ensure social peace. Industrial and social rationalization and stabilization, and the social benefits of a more efficient corporate system were the key values. The policy planning groups involved the same businessmen and academics who would later help formulate the Social Security Act. These groups and certain liberal businessmen began to participate in government studies on unemployment insurance and began to push for state legislation and private pension plans that would serve as exemplars for the Social Security Act. These exemplars specifically centered on rationalizing and stabilizing industry. Social justice for the worker was a subsidiary concern. The Social Security Act was a culmination of corporate liberal ideas on unemployment-the need to have predictable and efficient labor and consumer markets through payments to those previously tied to the labor market, and the need to smooth out business cycles. Old age insurance was likewise viewed as a means to remove inefficient
Corporate Liberalism and the Social Security Act

older workers from the labor force and put more money in consumers' pockets. In addition, both unemployment and old age insurance were contingent on labor force participation and in fact excluded large numbers of the labor force that were not tied to mainstream industry (such as agricultural workers, domestic servants and seamen), reinforcing dependency on the labor market for subsistence. Hence the Act was formulated with the interests of industry foremost.

By looking at how the problems of unemployment and old age security were defined and solutions formulated, we can see that the Social Security Act was not the result of compromises of varying interests. It involved compromise, but at a level that already defined the interests of capital as the ones of primary concern. No alternative noncorporate liberal concerns were able to gain access into the policy formation process. The Act and its formulation did reflect the ultimate dominance of capitalist interests and consequently the dominance of the capitalist class. But it is important to see that the Act was not entirely the result of the structure of capitalism or the desires of a corporate elite. The research points to a dialectical relationship between actors and social structure-an interplay between the ideas of corporate liberalism and how they were developed by powerful actors who were trying to deal with the social unrest, depressions and instability generated by a capitalist system. A discourse developed that created the perception of social problems and their solutions in terms of the best way to maintain the existing set of capitalist relations, and the Social Security Act was'a reflection of this discourse. Therefore, it is important to look at how policy options are determined before a specific policy is formulated in order to understand the relationship between ideology, particular social actors and a particular environment which, in this case, sustained the capitalist order in our society.

\section{FOOTNOTES}

1. These can be grouped into two kinds of organizations. The first attempted to generate broad consensus on policy reforms and included business and academics with labor representatives as junior partners in their memberships. The second group were the research organizations that collected facts needed to propose reforms. Many of the same liberal businessmen and academics were involved in both groups. Typically, big business donated money and controlled the research agenda from boards of trustees while academics conducted the research. 


\section{BIBLIOGRAPHY}

Berkowitz, Edward and Kim McQuaid

1978 "Businessman and Bureaucrat: The Evolution of the American Social Welfare System, 1900-1940." Journal of Economic History 27 (1):120 141, March.

Block, Fred

1977 "The Ruling Class does not Rule: Notes on the Marxist Theory of the State." Socialist Revolution 33 (May-June):6-28.

Chambers, Clarke A.

1963 Seedtime of Reform: American Social Service and Social Administration, 1918-1933. Minnesota: University of Minnesota Press.

Commons, John R.

1934 Myself. New York: MacMillan Company.

1959 Institutional Economics. Madison: University of Wisconsin Press. Domhoff, G. William

1970 The Higher Circles, The Governing Class in America. New York: Random House.

1978 The Powers That Be. New York: Vintage Books.

Dorfman, Joseph

1949 The Economic Mind in American Civilization, Volume Three, 1865 1918. New York: The Viking Press.

1955 The Economic Mind in American Civilization, Volumes Four and Five, 1918-1933. New York: The Viking Press.

Eakins, David

1966 "The Development of Corporate Liberal Policy Research in the United States, 1885-1965." Ph.D. Dissertation, University of Wisconsin.

Ely, Richard T.

1894 Socialism: An Examination of Its Nature, Its Strengths and Its Weaknesses. New York: T.Y. Cromwell.

Fine, Sidney

1956 Laissez Faire and the General-Welfare State; A Study of Conflict in American Thought, 1865-1901. Ann Arbor: University of Michigan Press.

Ginsburg, Norman 1979 Class, Capital and Social Policy. London: MacMillan Press.

Gough, Ian

1979 The Political Economy of the Welfare State. London: MacMillan Press. Greenough, William C. and Francis P. King

1976 Pension Plans and Public Policy. New York: Columbia University Press. Harter, Lafayette G., Jr.

1962 John R. Commons: His Assault on Laissez Faire. Corvallis: Oregon Kolko, Gabriel State University Press.

1963 Triumph of Conservatism. Chicago: Quadrangle.
Loth, David

1958 Swope of G.E. New York: Simon and Schuster.

Lubove, Roy

1968 The Struggle for Social Security, 1900-1935. Massachusetts: Harvard University Press.

McCarthy, Charles

1912 The Wisconsin Idea. New York: MacMillan.

McQuaid, Kim

1978 "Corporate Liberalism in the American Business Community, 19201940." Business History Review 52:342-68, Autumn.

1982 Big Business and President Power from FDR to Reagan. New York: William Morrow and Company, Inc.

O'Connor, James

1973 The Fiscal Crisis of the State. New York: St. Martin's Press.

Pratt, Henry J.

1976 The Gray Lobby. Chicago: University of Chicago Press.

Radosh, Ronald

1972 "The Myth of the New Deal." In Radosh \& Rothbard, A New History of Leviathan. New York: E.P. Dutton \& Company.

Rimlinger, Gaston V.

1971 Welfare Policy and Industrialization in Europe, America and Russia. New York: Wiley and Sons.

Sanders, Daniel S.

1973 The Impact of Reform Movements on Social Policy Change: The Case of Social Insurance. New Jersey: Burdick Inc.

Skocpol, Theda and John Henberry

1982 "The Political Formation of the American Welfare State in Historical and Comparative Perspective." Paper presented at the American Sociological Association Meetings, San Francisco.

Skocpol, Thed

1980 "Political Response to Capitalist Crisis: Neo-Marxist Theories of the State and the Case of the New Deal." Politics and Society 10 (2):155.

U.S. Congress, House, Committee on Ways and Means

1935 Economic Security Act. Hearings before the Committee on Ways and Means, House of Representatives, on HR 4120. 74th Congress, 1st Session, January 21 to February 12, 1935. Washington, D.C.: United States Government Printing Office.

U.S. Congress, Senate, Committee on Finance

1935 Economic Security Act. Hearings before the Committee on Finance, United States Senate, on S 1130. 74 th Congress, 1st Session, January 22 to February 20, 1935. Washington, D.C.: United States Government Printing Office.

United States Social Security Board

1937 Social Security in America: The Factual Background of the Social Security Act as Summarized from Staff Reports to the Committee on Economic Security. Washington, D.C.: United States Government Printing Office. 
Weinstein, James

1968 The Corporate Ideal in the Liberal State 1900-1918. Boston: Beacon Press.

Witte, Edwin E.

1962 The Development of the Social Security Act. A memorandum on the history of the Committee on Economic Security and drafting and legislative history of the Social Security Act. Madison: University of Wisconsin Press.
THE ELDERLY OF HISPANIC ORIGIN: POPULATION CHARACTERISTICS FOR 1980

\section{Elena Bastida}

Wichita State University

Mid-American Review of Sociology, 1984, Vol. IX, No. 1:41-47

Among the most significant trends of the twentieth century has been the continued growth of elderly populations, both in absolute numbers and in relation to other segments of American society. Population projections for the United States suggest that the number of elderly will continue to increase relative to other age groups. These projections also suggest that there will be an increase in the number of minority older persons 65 years of age or older. Presently, members of national minority groups make up a small proportion of the aged population. In 1980 about 11.7 percent of the 65 and over population were Black, 3 percent were Hispanic, 1.5 percent were Asians and less than 0.6 percent were Native American. Minority populations tend to be younger with much smaller percentages of older persons than Whites. For example, about 7.9 percent of the Black population is 65 years of age or older, compared to about 4.9 percent of Hispanics, somewhat over 5.3 percent of Asian Americans and a little more than 5.3 percent of the Native American population.

It must be noted, however, that some subgroups within the Hispanic cluster are not consistent with the broad pattern presented above. It is important to recognize that life experiences, broad demographic factors and structural conditions suggest considerable variations between them that is not easily gleaned from aggregated data. This paper, therefore, focuses on salient demographic trends regarding each subgroup within the Hispanic cluster (i.e., Mexican, Puerto Rican and Cuban) and examines dissimilarities in life expectancy, educational achievement, economic status and regional distribution which are attributable to within cluster structural deprivation and not to cultural disparities. An underlying assumption of this paper is that inequalities in American society have generated many of the observed sociodemographic variations among subgroups of older Hispanics. Furthermore, the demographic characteristics exhibited by either the cluster, the subgroup, or both primarily reflect the minority status of this population within the larger structure of American society and as such are independent of cultural influences. Lastly, it is the author's view that the "double jeopardy" hypothesis, about which much has been written 